\title{
Synthesis and Reactivity of the Phosphorus Analogues of Cyclopentadienone, Tricyclopentanone, and Housene
}

\section{Krachko, Tetiana}

2018-02-05

Krachko , T , Ehlers , A W , Nieger , M , Lutz , M \& Slootweg , J C 2018 , ' Synthesis and Reactivity of the Phosphorus Analogues of Cyclopentadienone, Tricyclopentanone, and Housene ' , Angewandte Chemie (International Edition) , vol. 57 , no. 6 , pp. 1683-1687 . https://doi.org/10.1002/anie

http://hdl.handle.net/10138/324830

https://doi.org/10.1002/anie.201711838

unspecified

acceptedVersion

Downloaded from Helda, University of Helsinki institutional repository.

This is an electronic reprint of the original article.

This reprint may differ from the original in pagination and typographic detail.

Please cite the original version. 


\title{
Synthesis and Reactivity of the Phosphorus Analogues of Cyclopentadienone, Tricyclopentanone, and Housene
}

\author{
Tetiana Krachko, ${ }^{[a]}$ Andreas W. Ehlers, ${ }^{[a, b]}$ Martin Nieger, ${ }^{[c]}$ Martin Lutz, ${ }^{[d]}$ and J. Chris Slootweg ${ }^{\star[a]}$
}

Dedicated to Professor Koop Lammertsma

\begin{abstract}
The phosphorus analogues of cyclopentadienone, tricyclopentanone and housene were accessed from bis(cyclopropenyl)diphosphetanedione $\mathbf{3}$, that was prepared by mixing 1,2,3-tris-tert-butylcyclopropenium tetrafluoroborate (1) and sodium phosphaethynolate $\left[\mathrm{Na}(\mathrm{OCP})(\text { dioxane })_{n}\right]$. While photolysis of 3 results in decarbonylation yielding bis(cyclopropenyl)diphosphene 4 and after rearrangement diphosphahousene $\mathbf{5}$, thermolysis of $\mathbf{3}$ leads to phosphatricyclo[2.1.0.0]pentanone 7. Metal-mediated valence isomerization of $\mathbf{7}$ and subsequent demetallation provides access to phosphacyclopentadienone $\mathbf{1 2}$
\end{abstract}

Pericyclic reactions are a powerful, atom economical tool to provide access to strained ring systems with interesting topology A striking example is the photoisomerization of tetra-tertbutylcyclopentadienone A $\left(R, R^{\prime}=t B u\right.$; Scheme 1$),{ }^{1}$ a key cooperative ligand in Shvo's catalyst. ${ }^{2}$ Upon excitation $(254 \mathrm{~nm})$ A exclusively gives tricyclo[2.1.0.0 2,5]pentan-3-one B, which either converts to cyclopropenylketene $\mathbf{C}$ or releases carbon monoxide to afford the highly strained tetrahedrane $\mathbf{D}$. On the other hand, irradiation of tris-tert-butyl-substituted dienone $\mathbf{A}(\mathrm{R}$ $\left.=t \mathrm{Bu}^{\prime} \mathrm{R}^{\prime}=\mathrm{H}\right)$ yields the thermally unstable housenone $\mathbf{E}(\mathrm{X}=$ $\mathrm{CO})$ that provides the antiaromatic cyclobutadiene $\mathbf{F}$ via $\mathrm{CO}$ elimination. ${ }^{3}$ To date, only one thermally stable, all-carbon housene $\mathbf{E}\left(\mathrm{X}=\mathrm{CH}_{2}, \mathrm{R}=t \mathrm{Bu}, \mathrm{R}^{\prime}=\mathrm{CO}_{2} t \mathrm{Bu}\right)^{4,5}$ is reported. Incorporation of heteroatoms like phosphorus into these molecules is appealing due to their propensity to accommodate small angles and, at the same time, provide a coordination site. So far, studies on the phosphorus analogues of $\mathbf{A}-\mathbf{F}$ are scarce, ${ }^{6}$ and only Cowley's diphosphatricyclopentanone G, ${ }^{7}$ Nixon's triphospha-analogue of housene $\mathbf{H}^{8}$ and Sekiguchi's monophospha-housene $\mathrm{I}^{9}$ are reported.

[a] T. Krachko, Dr. A. W. Ehlers, Assoc. Prof. Dr. J. C. Slootweg Van 't Hoff Institute for Molecular Sciences

University of Amsterdam, Science Park 904, PO Box 94157 1090 GD Amsterdam (The Netherlands)

E-mail: j.c.slootweg@uva.nt

[b] Dr. A. W. Ehlers

Department of Chemistry, Science Faculty

University of Johannesburg

PO Box 254, Auckland Park, Johannesburg (South Africa)

[c] Dr. M. Nieger

Department of Chemistry University of Helsink

A. I. Virtasen aukio 1, PO Box 55, Helsinki (Finland)

[d] Dr. M. Lutz

Crystal and Structural Chemistry

Bijvoet Center for Biomolecular Research, Utrecht University

Padualaan 8, $3584 \mathrm{CH}$ Utrecht (The Netherlands)

Supporting information for this article is given via a link at the end of the document.

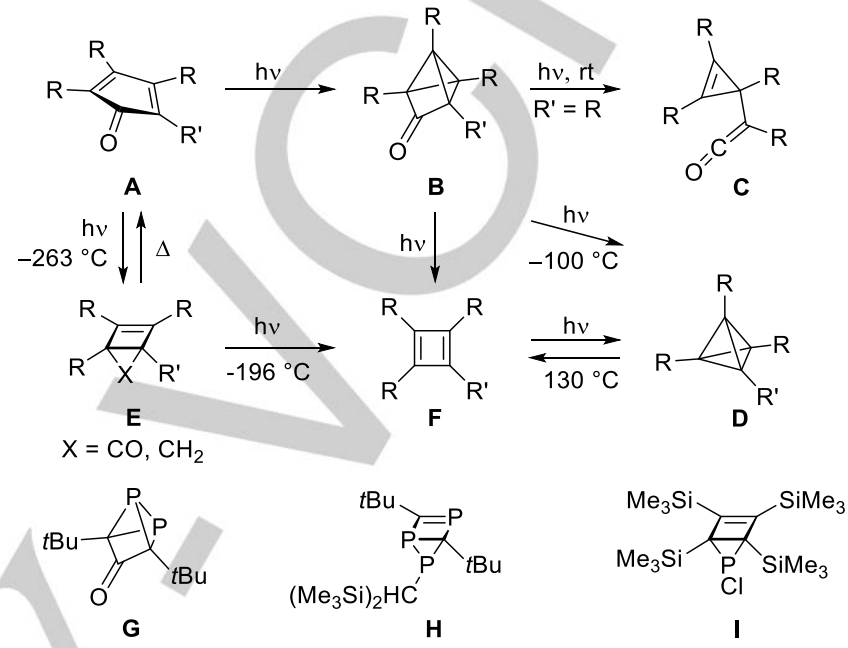

Scheme 1. Illustrative examples of strained ring systems.

We anticipated the phosphorus analogue of $\mathbf{C}$ (cyclopropenylphosphaketene 2; Scheme 2) ${ }^{10}$ to be an ideal entry point into this chemistry, as both the needed cyclopropenium cations and the phosphaethynolate anion (OCP)$^{11}$ are nowadays readily available. In this study, we focus on 1,2,3-tris-tert-butylcyclopropenium tetrafluoroborate (1). ${ }^{12}$ Addition of toluene to a mixture of $\left.[\mathrm{Na}(\mathrm{OCP}) \text { (dioxane })_{n}\right](n=2.5-$ 2.8) and 1 at $-78{ }^{\circ} \mathrm{C}$ gave a $1: 1$ mixture of $2\left(\delta^{31} \mathrm{P}\left\{{ }^{1} \mathrm{H}\right\}=-231.7\right.$ ppm) and $3\left(\delta^{31} \mathrm{P}\left\{{ }^{1} \mathrm{H}\right\}=119.0 \mathrm{ppm} \text {; Scheme } 2\right)^{13}$ that within 18 hours at $20^{\circ} \mathrm{C}$ fully converts into 1,3-diphosphetane-2,4-dione 3, which was isolated as a yellow powder in $97 \%$ yield $\left(\delta^{31} \mathrm{P}\left\{{ }^{1} \mathrm{H}\right\}=\right.$ $119.0 \mathrm{ppm} ; \delta^{13} \mathrm{C}\left\{{ }^{1} \mathrm{H}\right\}=224.8 \mathrm{ppm},{ }^{1} J_{\mathrm{C}, \mathrm{P}}=43.5 \mathrm{~Hz}, \mathrm{CO} ; \mathrm{v}(\mathrm{CO})=$ $\left.1627 \mathrm{~cm}^{-1}\right) \cdot{ }^{11 \mathrm{~b}}$ Evidently, intermediate 2, which we attribute to the phosphorus analogue of $\mathbf{C},{ }^{14}$ dimerizes via a facile head-totail [2+2] cycloaddition of the $\mathrm{P}=\mathrm{C}$ bonds to yield $3,{ }^{15}$ which is also supported by DFT calculations at the $\omega \mathrm{B} 97 \mathrm{X}-\mathrm{D} / 6-31 \mathrm{G}(\mathrm{d}, \mathrm{p})$ level of theory $\left(\Delta E=-24.4 \mathrm{kcal} \cdot \mathrm{mol}^{-1} ; \Delta E^{\ddagger}=10.6 \mathrm{kcal} \cdot \mathrm{mol}^{-1}\right.$; ZPE corrected). ${ }^{13}$

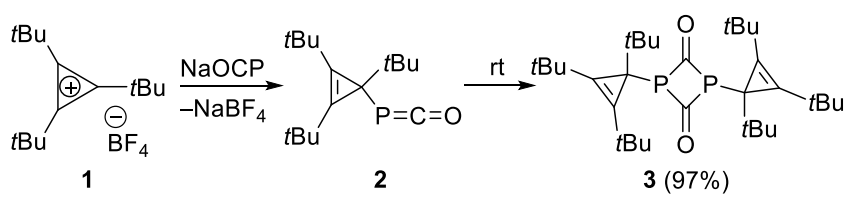

Scheme 2. Synthesis of 1,3-diphosphetane-2,4-dione 3.

Diphosphetanedione $\mathbf{3}$ is stable under an inert atmosphere, but light sensitive. In daylight, it slowly releases $\mathrm{CO}$, while irradiation with a xenon lamp quantitatively converts a bright yellow toluene solution of $\mathbf{3}$ to the orange diphosphene $\mathbf{4}$ (3 h, rt), 
which was isolated after removal of all volatiles in $99 \%$ yield (Scheme 3; $\left.\delta^{31} \mathrm{P}\left\{{ }^{1} \mathrm{H}\right\}=585.3 \mathrm{ppm}\right) .{ }^{16,17}$ The molecular structure of 4 , determined by a single-crystal $X$-ray structure determination (Figure 1, top left), ${ }^{18}$ reveals a centrosymmetric diphosphene with typical P1-P1a $(2.0210(6) \AA)$ and P1-C1 $(1.8778(12) \AA$ ) bond lengths and a syn conformation (P1a-P1C1-C4 $171.67(4)^{\circ}$ ) of the cyclopropenyl groups and the $P=P$ double bond. Note, the related bis(pentamethylcyclopentadienyl) diphosphene $\left(C p^{*} \mathrm{P}=\mathrm{PCp} \mathrm{p}^{*}\right)$ has the cyclopentadienyl rings and $\mathrm{P}=\mathrm{P}$ bond positioned anti to each other. ${ }^{19} \omega \mathrm{B} 97 \mathrm{X}-\mathrm{D} / 6-31 \mathrm{G}(\mathrm{d}, \mathrm{p})$ calculations $^{13}$ revealed this difference is of steric nature. The bulky tert-butyl group at $\mathrm{C} 1$ in $\mathbf{4}$ destabilizes the anti conformation $\left(\Delta E_{\text {anti-syn }}=8.0 \mathrm{kcal} \cdot \mathrm{mol}^{-1}\right)$, while the anti conformer is favored for the corresponding methyl-C1 analogue $\left(\Delta E_{\text {anti-syn }}=\right.$ $\left.-1.1 \mathrm{kcal} \cdot \mathrm{mol}^{-1}\right) .^{13}$

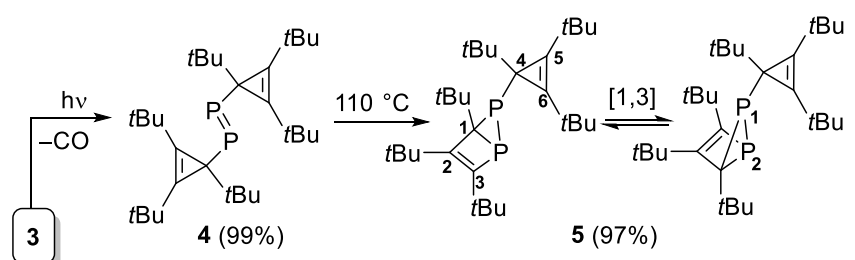

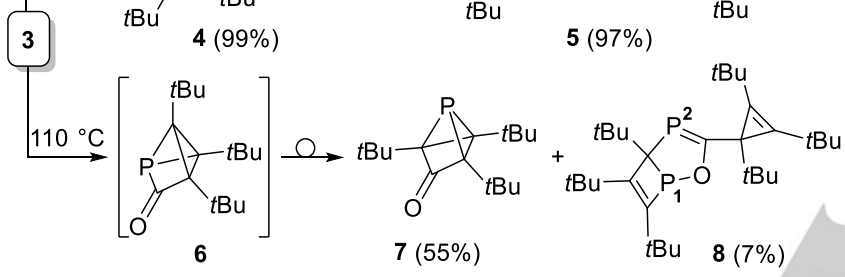

Scheme 3. Photolysis and thermolysis of 1,3-diphosphetane-2,4-dione 3.
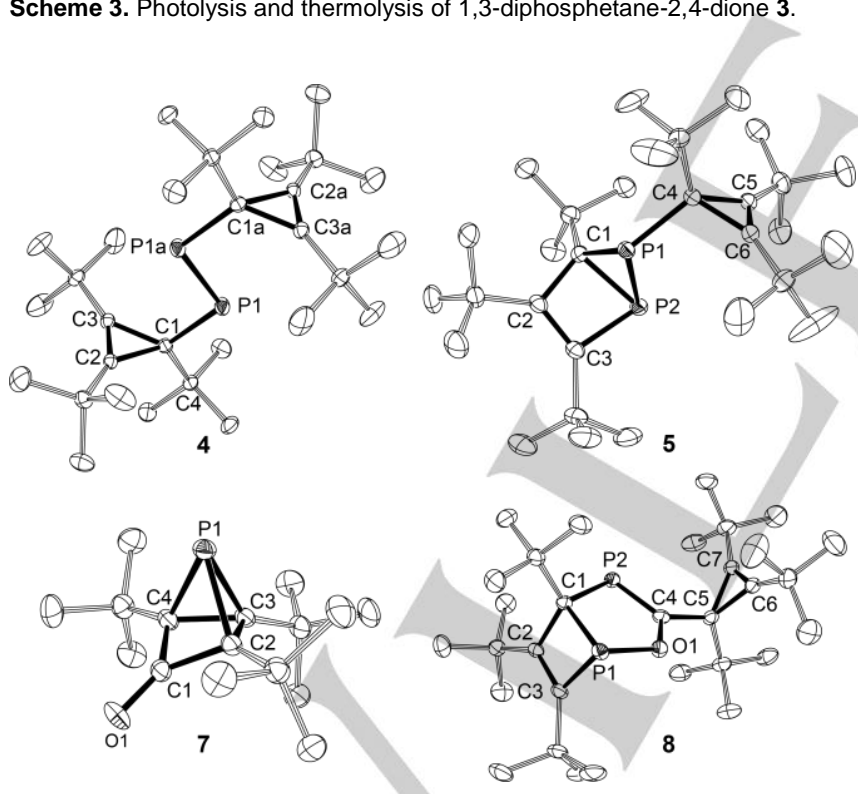

Figure 1. Molecular structures of 4, 5, 7 and 8 (ellipsoids at $50 \%$ probability hydrogen atoms omitted for clarity). Selected bond lengths $[\AA]$ and angles $\left[{ }^{\circ}\right]$ for 4: P1-P1a 2.0210(6), P1-C1 1.8778(12), C1-C2 1.5209(16), C1-C3 1.5212(16), C2-C3 1.2938(17); P1a-P1-C1 102.88(4); P1a-P1-C1-C4 171.67(4). 5: P1-P2 2.2080(6), P1-C1 1.8959(17), P1-C4 1.8909(16), P2-C1 1.8765(17), P2-C3 1.8487(17), C1-C2 1.548(2), C2-C3 1.362(2); P2-P1-C1 53.77(5); C3-P2-C1-C2 1.36(10). 7: P1-C2 1.9198(12), P1-C3 1.8081(12), $\mathrm{P} 1-\mathrm{C} 4$ 1.9293(13); C2-P1-C3 49.03(5), C3-P1-C4 48.77(5), C4-P1-C2 66.15(5); C2-P1-C3-C4 92.80(8). 8: P1-O1 1.6896(12), C1-P1 1.8774(16), C1-C2 1.562(2), C2-C3 1.366(2), C3-P1 1.8110(17), P2-C1 1.8795(16), P2-
C4 1.6926(17), C4-O1 1.3795(18); C3-P1-C1-C2 3.49(9), O1-P1-C1P2 -1.66(8).

Next, we studied the thermal stability of $\mathbf{4}$ and discovered a rare pericyclic rearrangement for a diphosphene. ${ }^{20}$ Heating 4 for 20 hours in refluxing toluene afforded $\mathbf{5}$, which displays two different ${ }^{31} \mathrm{P}\left\{{ }^{1} \mathrm{H}\right\}$ NMR resonances and was isolated as a pale yellow solid in $97 \%$ yield (Scheme 3; $\delta^{31} \mathrm{P}\left\{{ }^{1} \mathrm{H}\right\}=53.5(\mathrm{P} 1)$, $169.1 \mathrm{ppm}(\mathrm{P} 2),{ }^{1} \mathrm{~J}_{\mathrm{P}, \mathrm{P}}=171.0 \mathrm{~Hz}$ ). Single-crystal X-ray structure determination provided unequivocally the molecular structure of 5 (Figure 1, top right), ${ }^{18}$ which displays a diphosphahousene motif with a dihedral angle of $99.7^{\circ}$ between the threemembered diphosphirane and the almost planar 4-membered phosphacyclobutene moiety (C3-P2-C1-C2 1.36(10) ${ }^{\circ}$ ). Although diphosphahousene $5\left(\mathrm{P}_{2}-\mathrm{E}\right)$ bears six inequivalent tert-butyl groups, only 4 different ${ }^{1} \mathrm{H}$ and ${ }^{13} \mathrm{C}\left\{{ }^{1} \mathrm{H}\right\}$ NMR resonances were found at room temperature. Upon cooling to $-80^{\circ} \mathrm{C}$, the expected 6 sets of $t \mathrm{Bu}$ signals were observed, indicating that 5 is dynamic at room temperature and undergoes a facile degenerate $[1,3]$ sigmatropic shift (see Scheme 3), ${ }^{21}$ which was supported by theory $\left(\Delta E^{\ddagger}=17.5 \mathrm{kcal} \cdot \mathrm{mol}^{-1}\right.$ at $\omega \mathrm{B} 97 \mathrm{X}-\mathrm{D} / 6$ $31 \mathrm{G}(\mathrm{d}, \mathrm{p})),{ }^{13,22}$ and also found for triphosphahousene $\mathbf{H} .^{8}$

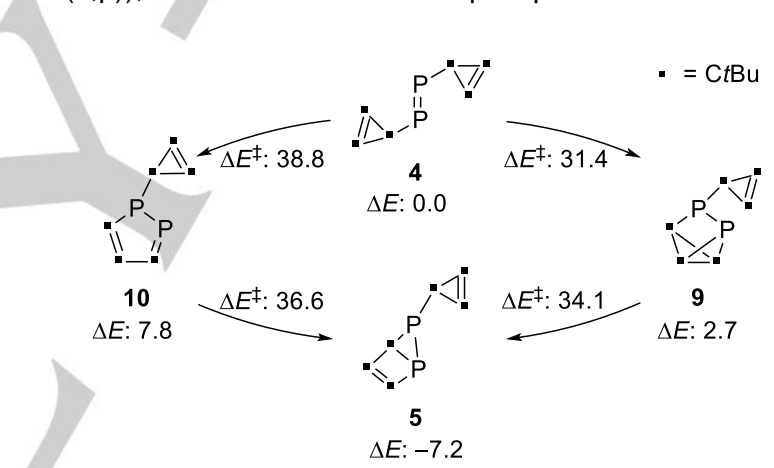

Scheme 4. Relative $\omega B 97 X-D / 6-31 G(d, p)$ energies (ZPE corrected, in $\mathrm{kcal} \cdot \mathrm{mol}^{-1}$ ) for the rearrangement of diphosphene 4 to give $\mathbf{5} \cdot{ }^{-}=\mathrm{C} t \mathrm{Bu}$

To gain more insight into the mechanism of the unusual 45 rearrangement, we resorted again to DFT calculations ${ }^{13}$ and found that 4 undergoes a [2+2] cycloaddition between the $P=P$ and $\quad \mathrm{C}=\mathrm{C}$ bonds affording P-bridged phosphabicyclo[1.1.0]butane 9 as intermediate $(\Delta E=2.7$ $\mathrm{kcal} \cdot \mathrm{mol}^{-1}, \Delta E^{\ddagger}=31.4 \mathrm{kcal} \cdot \mathrm{mol}^{-1}$; Scheme 4$) .9$ cannot undergo the classical bicyclo[1.1.0]butane-butadiene rearrangement to give diphosphacyclopentadiene $\mathbf{1 0}$ due to geometrical constraints, ${ }^{23}$ but affords $\mathbf{5}$ instead via an unprecedented tricyclopentane-housene rearrangement $\left(\Delta E=-7.2 \mathrm{kcal} \cdot \mathrm{mol}^{-1}\right.$, $\Delta E^{\ddagger}=34.1 \mathrm{kcal} \cdot \mathrm{mol}^{-1}$ ). In principle, 4 can also provide 5 via a vinylcyclopropene-cyclopentadiene rearrangement ${ }^{24}$ affording $10\left(\Delta E=7.8 \mathrm{kcal} \cdot \mathrm{mol}^{-1}, \Delta E^{\ddagger}=38.8 \mathrm{kcal} \cdot \mathrm{mol}^{-1}\right)$, followed by an electrocyclic ring closure $\left(\Delta E^{+}=36.6 \mathrm{kcal} \cdot \mathrm{mol}^{-1}\right.$; Scheme 4$)$, but this is a higher energy process.

Next, we explored the thermal stability of diphosphetanedione $\mathbf{3}$ as a promising route to obtain the $P$ analogues of $\mathbf{A}$ and $\mathbf{B}$ (Scheme 1). Heating $\mathbf{3}$ in the dark for 20 hours in refluxing toluene results in the formation of $7\left(\delta^{31} \mathrm{P}\left\{{ }^{1} \mathrm{H}\right\}=\right.$ $\left.-384.1 \mathrm{ppm}, \mathrm{v}(\mathrm{CO})=1722 \mathrm{~cm}^{-1} ; 85 \%\right), 8\left(\delta^{31} \mathrm{P}\left\{{ }^{1} \mathrm{H}\right\}=134.5(\mathrm{P} 1)\right.$, 
$153.9 \mathrm{ppm}(\mathrm{P} 2),{ }^{2} J_{\mathrm{P}, \mathrm{P}}=4.8 \mathrm{~Hz} ; 12 \%$; Scheme 3) and an unidentified minor product $\left(\delta^{31} \mathrm{P}\left\{{ }^{1} \mathrm{H}\right\}=-177.0 \mathrm{ppm}\right.$; 3\%; Figures S9, S10). Major product 7 was isolated as colorless crystals in $55 \%$ yield by recrystallization of the crude from $\mathrm{Et}_{2} \mathrm{O}$ at $-78^{\circ} \mathrm{C}$ and was characterized crystallographically (Figure 1, bottom left). ${ }^{18}$ The molecular structure of 7 reveals a 1 phosphatricyclo[2.1.0.0]pentan-3-one framework $\left(P_{1}-B\right)$ with a remarkably small sum of angles at phosphorus $\left(163.95(9)^{\circ}\right)$, highlighting the tetrahedrane-type geometry. The transannular $\mathrm{P} 1-\mathrm{C} 3$ bond $(1.8081(12) \AA)$ of the bicyclobutane core is considerably shorter than the other two $\mathrm{P}-\mathrm{C}$ bonds (P1-C2 1.9198(12), P1-C4 1.9293(13) A), which points to a strongly bent $\sigma$-bond that was also reported for the all-carbon tricyclopentanones B. ${ }^{25} \omega \mathrm{B} 97 \mathrm{X}-\mathrm{D} / 6-31 \mathrm{G}(\mathrm{d}, \mathrm{p})$ calculations ${ }^{13}$ provided insight into the formation of $\mathbf{7}$ and revealed that phosphaketene $\mathbf{2}$ is an intermediate, that was also detected spectroscopically during the reaction (Figures S7, S8), which forms 2-phosphatricyclopentan-3-one 6 via a [2+2] cycloaddition $\left(\Delta E=-11.8 \mathrm{kcal} \cdot \mathrm{mol}^{-1}, \Delta E^{\ddagger}=25.9 \mathrm{kcal} \cdot \mathrm{mol}^{-1}\right.$; Scheme 3$)$. Subsequently, transient 6 undergoes a type । dyotropic rearrangement ${ }^{26}$ to alleviate steric strain of the three neighboring tert-butyl groups providing $7\left(\Delta E=-23.5 \mathrm{kcal} \cdot \mathrm{mol}^{-1}, \Delta E^{\ddagger}=30.4\right.$ $\left.\mathrm{kcal} \cdot \mathrm{mol}^{-1}\right)$. After separating 7 from the product mixture, column chromatography of the residue under an inert atmosphere afforded 2-oxa-1,4-diphosphabicyclo[3.2.0]hepta-3,6-diene 8 as a yellow crystalline solid in $7 \%$ yield (Scheme 3; Figure 1, bottom right), ${ }^{18}$ which formally results from a $[2+3]$ cycloaddition of the putative phosphacyclobutadiene ${ }^{27}$ and the rearranged phosphaketene 2, in analogy to the chemistry of (phosphanyl)phosphaketenes recently reported by Grützmacher, Bertrand and co-workers. ${ }^{28}$

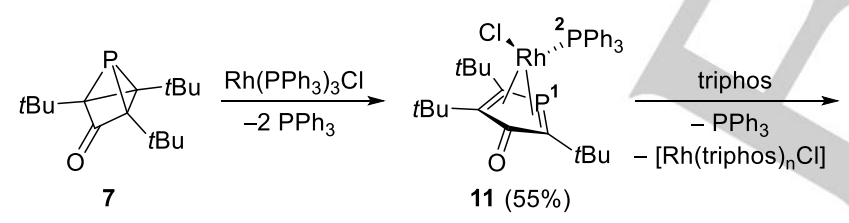

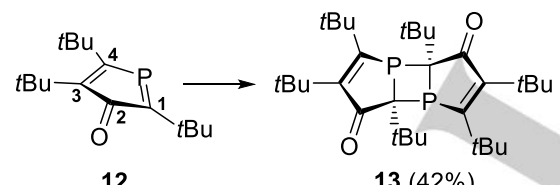

Scheme 5. Valence isomerization of tricyclopentanone $\mathbf{7}$ in the coordination sphere of $\mathrm{Rh}(\mathrm{I})$ and synthesis and dimerization of the uncomplexed phosphacyclopentadienone 12. Triphos $=\mathrm{CH}_{3} \mathrm{C}\left(\mathrm{CH}_{2} \mathrm{PPh}_{2}\right)_{3}, n=1$ or 2 .

To access the $\mathrm{P}_{1}-\mathbf{A}$, we targeted the metal-mediated valence isomerization of phosphatricyclopentanone 7. ${ }^{29}$ Satisfyingly, treatment of 7 with 1.0 equivalent of $\mathrm{RhCl}\left(\mathrm{PPh}_{3}\right)_{3}$ in refluxing dichloromethane afforded rhodium complex 11, which was isolated as brown crystals in $55 \%$ yield by recrystallization from $\mathrm{Et}_{2} \mathrm{O}$ at $-78{ }^{\circ} \mathrm{C}\left(\delta^{31} \mathrm{P}\left\{{ }^{1} \mathrm{H}\right\}: 32.9\left(\mathrm{dd},{ }^{1} \mathrm{~J}_{\mathrm{P}, \mathrm{Rh}}=171.2 \mathrm{~Hz}, \mathrm{~J}_{\mathrm{P}, \mathrm{P}}=\right.\right.$ $11.0 \mathrm{~Hz} ; \mathrm{P} 2),-24.9$ (dd, $\left.J_{\mathrm{P}, \mathrm{Rh}}=30.3 \mathrm{~Hz}, J_{\mathrm{P}, \mathrm{P}}=11.0 \mathrm{~Hz} ; \mathrm{P} 1\right)$ ppm; $v(\mathrm{CO})=1644 \mathrm{~cm}^{-1}$; Scheme 5). The molecular structure of 11 (Figure 2, left) ${ }^{18}$ revealed the formation of a unique $\left(\eta^{4}\right.$ phosphacyclopentadienone)rhodium(I) complex, which is the phosphorus analogue of $\left[\left(\mathrm{Ph}_{4} \mathrm{C}_{4} \mathrm{CO}\right) \mathrm{MCl}\left(\mathrm{PPh}_{3}\right) \mathrm{Cl}\right](\mathrm{M}=\mathrm{Rh}$, Ir), a key pre-catalyst for the acceptorless dehydrogenation by metalligand cooperation. ${ }^{30}$ The $\mathrm{PPh}_{3}$ ligand in $\mathbf{1 1}$ shows a strong trans-influence $\left(\mathrm{P} 2-\mathrm{Rh} 1-\mathrm{C} 4 \mathrm{169.20}(5)^{\circ}\right)$, which leads to elongation of the Rh1-C4 bond $(2.2595(16) \AA$ ) versus the shorter Rh1-C2 (2.2011(17) A) and Rh1-C5 bonds (2.1773(17) $\AA$ ).

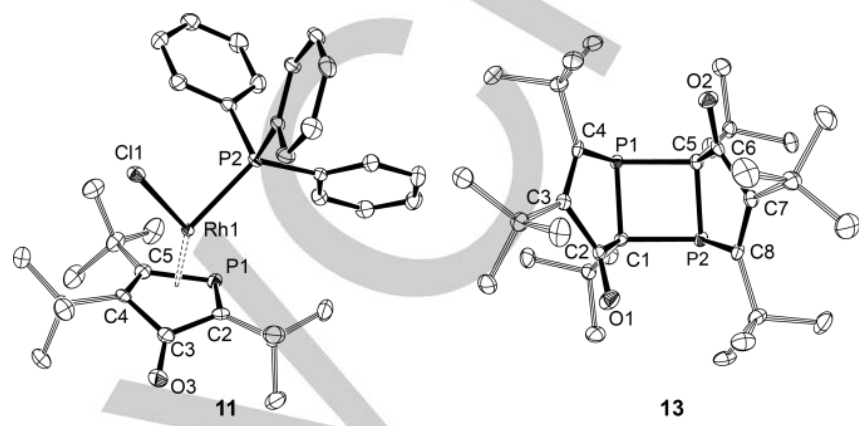

Figure 2. Molecular structures of $\mathbf{1 1}$ and $\mathbf{1 3}$ (ellipsoids at $50 \%$ probability hydrogen atoms are omitted for clarity). Selected bond lengths $[\AA]]$ and angles [] for 11: Rh1-P1 2.3297(5), Rh1-C2 2.2011(17), Rh1-C4 2.2595(16), Rh1C5 2.1773(17), Rh.C3 2.5917(18), Rh1-P2 2.3678(4), P1-C2 1.7616(19), P1-C5 1.8416(19); C4-Rh1-P2 169.20(5); C2-P1-C5-C4 -3.27(13). 13: P1-C1 1.858(2), P1-C5 1.916(3), C1-C2 1.513(3), C2-C3 1.515(3), C3-C4 1.361(3), C4-P1 1.857(2); P2-C1-P1 92.82(11), C1-P1-C5 85.64(11); P2-C1-P1-C5 12.36(10), C4-P1-C1-C2 -7.13(17).

Finally, we focused on the demetallation of 11. Addition of 1,1,1-tris(diphenylphosphinomethyl)ethane (triphos) to a dichloromethane solution of $\mathbf{1 1}$ at room temperature afforded within minutes selectively phosphacyclopentadienone $12\left(\delta^{31} \mathrm{P}=\right.$ $303.1 \mathrm{ppm} ; \delta^{13} \mathrm{C}=195.4 \mathrm{ppm}(\mathrm{P}=C),{ }^{1} \mathrm{~J}_{\mathrm{C}, \mathrm{P}}=31.4 \mathrm{~Hz}$; Scheme 5) together with a mixture of $\left[\mathrm{Rh}\right.$ (triphos) $\left.{ }_{n} \mathrm{Cl}\right]$ and $\mathrm{PPh}_{3}$, as confirmed by ${ }^{31} \mathrm{P},{ }^{1} \mathrm{H}$ and ${ }^{13} \mathrm{C}$ NMR spectroscopy (Figures $\mathrm{S} 11$ S13). Upon removal of the solvent, 12 rapidly dimerizes ${ }^{31}$ to bis(phosphole)-3,7-dione $\mathbf{1 3}$ as a single (endo) stereoisomer, which was isolated after column chromatography as a yellow solid in $42 \%$ yield $\left(\delta^{31} \mathrm{P}=-13.4 \mathrm{ppm}\right.$; Scheme 5) and characterized crystallographically (Figure 2 , right). ${ }^{18}$ The facile head-to-tail [2+2] dimerization of $\mathbf{1 2}$ was supported by DFT calculations, again at the $\omega \mathrm{B} 97 \mathrm{X}-\mathrm{D} / 6-31 \mathrm{G}(\mathrm{d}, \mathrm{p})$ level of theory, which revealed endo-13 to be thermodynamically and kinetically favored over exo-13 $\left(\Delta E=-50.8\right.$ versus $-36.3 \mathrm{kcal} \cdot \mathrm{mol}^{-1} ; \Delta E^{+}=$ 21.9 versus $25.2 \mathrm{kcal} \cdot \mathrm{mol}^{-1}$, respectively), which can be attributed to secondary orbital interactions in the transition state leading to the endo adduct. ${ }^{13}$

In summary, cyclopropenylphosphaketene 2 and its dimer 1,3-diphosphetane-2,4-dione $\mathbf{3}$ grant access to the phosphorus analogues of housene, tricyclopentanone and cyclopentadienone all of which display intriguing pericyclic reactions. Currently, we are developing decarbonylation strategies for phosphatricyclopentanone $7^{29}$ ultimately leading to the elusive phosphacyclobutadiene and phosphatetrahedrane.

\section{Acknowledgements}


This work was supported by the European Union (Marie Curie ITN SusPhos, Grant Agreement No. 317404) and the Council for Chemical Sciences of The Netherlands Organization for Scientific Research (NWO/CW) by a VIDI grant (J.C.S.). Prof. Dr. Hansjörg Grützmacher and Dr. Riccardo Suter are gratefully acknowledged for providing $\left[\mathrm{Na}(\mathrm{OCP})(\text { dioxane })_{n}\right]$.

Keywords: valence isomerization $\cdot$ phosphorus $\cdot$ small ring systems $\bullet$ pericyclic reactions $\cdot$ main-group elements

[1] a) G. Mayer, S. Pfriem, Angew. Chem. Int. Ed. Engl. 1978, 17, 519520; Angew. Chem. 1978, 90, 551-552; b) G. Mayer, S. Pfriem, U. Schäfer, R. Matusch, Angew. Chem. Int. Ed. Engl. 1978, 17, 520-521; Angew. Chem. 1978, 90, 552-553; c) G. Maier, S. Pfriem, U. Schäfer, K.-D. Malsch, R. Matusch, Chem. Ber. 1981, 114, 3965-3987.

[2] a) R. Karvembu, R. Prabhakaran, K. Natarajan, Coord. Chem. Rev. 2005, 249, 911-918; b) B. L. Conley, M. K. Pennington-Boggio, E. Boz, T. J. Williams, Chem. Rev. 2010, 110, 2294-2312.

[3] a) G. Maier, A. Alzérreca, Angew. Chem. Int. Ed. Engl. 1973, 12, 10151016; Angew. Chem. 1973, 85, 1056-1057; b) G. Maier, U. Schäfer, W. Sauer, H. Hartan, R. Matusch, G. F. M. Oth, Tetrahedron Lett. 1978, 19, 1837-1840.

[4] U.-J. Vogelbacher, P. Eisenbarth, M. Regitz, Angew. Chem. Int. Ed. Engl. 1984, 23, 708-710; Angew. Chem. 1984, 96, 691-693.

[5] Housene $\mathrm{E}\left(\mathrm{X}=\mathrm{C}(\mathrm{Me}) \mathrm{CO}_{2} \mathrm{Me}, \mathrm{R}=\mathrm{H}, \mathrm{R}\right.$ ' $\left.=\mathrm{Me}\right)$ undergoes a "walk" rearrangement at $0{ }^{\circ} \mathrm{C}$, in which the bridgehead group $\mathrm{CMe}\left(\mathrm{CO}_{2} \mathrm{Me}\right)$ migrates via [1,3]-sigmatropic shifts along the 4-membered ring with inversion of configuration at the bridgehead carbon, see: a) F.-G. Klärner, F. Adamsky, Angew. Chem. Int. Ed. Engl. 1979, 18, 674-675 Angew. Chem. 1979, 91, 738-739; b) R. F. Childs, Tetrahedron 1982, 38, 567-608; c) F.-G. Klärner, F. Adamsky, Chem. Ber. 1983, 116, 299-322; d) F. Jensen, J. Am. Chem. Soc. 1989, 111, 4643-4647.

[6] For metal-complexed diphospha-analogues of A, see: a) M. H. A. Benvenutti, P. B. Hitchcock, J. L. Kiplinger, J. F. Nixon, T. G. Richmond, Chem. Commun. 1997, 1539-1540; b) M. Scheer, J. Krug, Z. Anorg. Allg. Chemie 1998, 624, 399-405; c) U. Vogel, M. Eberl, M. Eckhardt, A. Seitz, E.-M. Rummel, A. Y. Timoshkin, E. V. Peresypkina, M. Scheer, Angew. Chem. Int. Ed. 2011, 50, 8982-8985; Angew. Chem. 2011, 123 9144-9148. For metal-complexed phospha-derivatives of $E$, see: d) V. Lyaskovskyy, N. Elders, A. W. Ehlers, M. Lutz, J. C. Slootweg, K. Lammertsma, J. Am. Chem. Soc. 2011, 133, 9704-9707; For a antimony-diphospha analogue of housene E, see: e) C. Fish, M. Green, J. C. Jeffery, R. J. Kilby, J. M. Lynam, J. E. McGrady, D. A. Pantazis, C. A. Russell, C. E. Willans, Angew. Chem. Int. Ed. 2006, 45, 6685-6689; Angew. Chem. 2006, 118, 6837-6841.

[7] A. R. Barron, A. H. Cowley, S. W. Hall, C. M. Nunn, Angew. Chem. Int. Ed. Engl. 1988, 27, 837-838; Angew. Chem. 1988, 100, 873-874.

[8] a) V. Caliman, P. B. Hitchcock, J. F. Nixon, Chem. Commun. 1998, 1537-1538; b) S. M. Bachrach, V. Caliman, J. F. Nixon, J. Chem. Soc. Chem. Commun. 1995, 255, 2395-2396.

[9] V. Y. Lee, H. Sugasawa, O. A. Gapurenko, R. M. Minyaev, V. I. Minkin, H. Gornitzka, A. Sekiguchi, Chem. Eur. J. 2016, 22, 17585-17589.

[10] For phosphaketenes created from the OCP anion, see: a) S. Alidori, D. Heift, G. Santiso-Quinones, Z. Benkö, H. Grützmacher, M. Caporali, L. Gonsalvi, A. Rossin, M. Peruzzini, Chem. Eur. J. 2012, 18, 1480514811; b) L. Liu, D. A. Ruiz, F. Dahcheh, G. Bertrand, R. Suter, A. M. Tondreau, H. Grützmacher, Chem. Sci. 2016, 7, 2335-2341; c) N. Del Rio, A. Baceiredo, N. Saffon-Merceron, D. Hashizume, D. Lutters, T. Müller, T. Kato, Angew. Chem. Int. Ed. 2016, 55, 4753-4758; Angew. Chem. 2016, 128, 4831-4836; d) Y. Xiong, S. Yao, T. Szilvási, E. Ballestero-Martínez, H. Grützmacher, M. Driess, Angew. Chem. Int. Ed. 2017, 56, 4333-4336; Angew. Chem. 2017, 129, 4397-4400
[11] Synthesis of $[\mathrm{Na}(\mathrm{OCP})($ dioxane) $n]$, see: a) F. F. Puschmann, D. Stein, D. Heift, C. Hendriksen, Z. A. Gal, H.-F. Grützmacher, H. Grützmacher, Angew. Chem. Int. Ed. 2011, 50, 8420-8423; Angew. Chem. 2011, 123, 8570-8574; b) D. Heift, Z. Benkö, H. Grützmacher, Dalton Trans. 2014, 43, 831-840; c) I. Krummenacher, C. C. Cummins, Polyhedron 2012, $32,10-13$.

[12] 1 has been successfully applied in the synthesis of cyclobutadienes E, see: a) S. Masamune, N. Nakamura, M. Suda, H. Ona, J. Am. Chem. Soc. 1973, 95, 8481-8483; b) H. Wingert, M. Regitz, Chem. Ber. 1986, $119,244-256$

[13] See the Supporting Information for further details.

[14] For phosphaketenes, see: a) R. Appel, W. Paulen, Tetrahedron Lett. 1983, 24, 2639-2642; b) R. Appel, W. Paulen, Angew. Chem. Int. Ed. Engl. 1983, 22, 785-786; Angew. Chem. 1983, 95, 807-808; c) Z. Li, X. Chen, M. Bergeler, M. Reiher, C.-Y. Su, H. Grützmacher, Dalton Trans. 2015, 44, 6431-6438.

[15] U. Salzner, S. M. Bachrach, J. Am. Chem. Soc. 1994, 116, 6850-6855.

[16] For reviews, see: a) L. Weber, Chem. Rev. 1992, 92, 1839-1906; b) M. Yoshifuji, Eur. J. Inorg. Chem. 2016, 607-615.

[17] Note that carbon monoxide release from phosphaketenes to form diphosphenes has been recently observed, see: a) L. Liu, D. A. Ruiz, D. Munz, G. Bertrand, Chem 2016, 1, 147-153; b) M. M. Hansmann, R. Jazzar, G. Bertrand, J. Am. Chem. Soc. 2016, 138, 8356-8359; c) L. Liu, D. A. Ruiz, F. Dahcheh, G. Bertrand, R. Suter, A. M. Tondreau, H. Grützmacher, Chem. Sci. 2016, 7, 2335-2341; d) Y. Xiong, S. Yao, T. Szilvási, E. Ballestero-Martínez, H. Grützmacher, M. Driess, Angew. Chem. Int. Ed. 2017, 56, 4333-4336; Angew. Chem. 2017, 129, 4397 4400. For a theoretical study on the coordination of $\mathrm{CO}$ to low-valent phosphorus centres, see: e) G. von Frantzius, A. Espinosa Ferao, R. Streubel, Chem. Sci. 2013, 4, 4309-4322.

[18] CCDC 1583606 (4), 1583607 (5), 1584611 (7), 1584612 (8), 1583608 (11), 1584613 (13) contain the supplementary crystallographic data for this paper. These data can be obtained free of charge from The Cambridge Crystallographic Data Centre via www.ccdc.cam.ac.uk/data_request/cif. For the experimental details of the X-ray crystal structure determinations, see the Supporting Information.

[19] a) P. Jutzi, U. Meyer, B. Krebs, M. Dartmann, Angew. Chem. Int. Ed. Engl. 1986, 25, 919-921; Angew. Chem. 1986, 98, 894-895; b) P. Jutzi, U. Meyer, J. Organomet. Chem. 1987, 333, C18-C20.

[20] An intramolecular electrocyclization product has been proposed only as an intermediate in a dimerization reaction, see: ref. [16a]

[21] R. E. Bulo, H. Jansen, A. W. Ehlers, F. J. J. de Kanter, M. Schakel, M. Lutz, A. L. Spek, K. Lammertsma, Angew. Chem. Int. Ed. 2004, 43, 714-717; Angew. Chem. 2004, 116, 732-735.

[22] The full "walk" of the $\mathrm{P}_{1} \mathrm{C}_{3}(\mathrm{tBu})_{3}$ moiety over the phosphacyclobutadiene ring in $\mathbf{5}$ is prohibited, since the $[1,3]$ sigmatropic shift from $\mathrm{P} 2$ to $\mathrm{C} 2$ is endothermic $\left(\Delta E=23.0 \mathrm{kcal} \cdot \mathrm{mol}^{-1}\right)$ due to the formation of an intermediate with a $\mathrm{P}=\mathrm{C}$ instead of a $\mathrm{C}=\mathrm{C}$ bond.

[23] a) J. C. Slootweg, S. Krill, F. J. J. de Kanter, M. Schakel, A. W. Ehlers, M. Lutz, A. L. Spek, K. Lammertsma, Angew. Chem. Int. Ed. 2005, 44, 6579-6582; Angew. Chem. 2005, 117, 6737-6740; b) J. C. Slootweg, A. W. Ehlers, K. Lammertsma, J. Mol. Model. 2006, 12, 531-536.

[24] H. E. Zimmerman, D. W. Wilson, J. Org. Chem. 1995, 60, 692-697.

[25] H. Irngartinger, A. Goldmann, Angew. Chem. Int. Ed. Engl. 1982, 21, 775-776; Angew. Chem. 1982, 94, 786-787.

[26] a) I. Fernández, F. P. Cossío, M. A. Sierra, Chem. Rev. 2009, 109, $6687-6711$; b) H. V. Pham, A. S. Karns, C. D. Vanderwal, K. N. Houk, J. Am. Chem. Soc. 2015, 137, 6956-6964.

[27] We speculate that phosphacyclobutadiene forms through elimination of $\mathrm{CO}$ from 6 or $\mathbf{7}$, akin to their hydrocarbon derivatives B, see: $\mathrm{H}$. Ona, $\mathrm{H}$. Yamaguchi, S. Masamune, J. Am. Chem. Soc. 1970, 92, 7495-7497.

[28] Z. Li, X. Chen, Z. Benkö, L. Liu, D. A. Ruiz, J. L. Peltier, G. Bertrand, C.-Y. Su, H. Grützmacher Angew. Chem. Int. Ed. 2016, 55, 6018-6022; Angew. Chem. 2016, 128, 6122-6126. 
[29] H. Ona, M. Sakai, M. Suda, S. Masamune, J. Chem. Soc. Chem. Commun. 1973, 45-46.

[30] S. Kusumoto, M. Akiyama, K. Nozaki, J. Am. Chem. Soc. 2013, 135, 18726-18729.

[31] L. N. Markovski, V. D. Romanenko, Tetrahedron 1989, 45, 6019-6090. 


\section{Entry for the Table of Contents}

\section{COMMUNICATION}

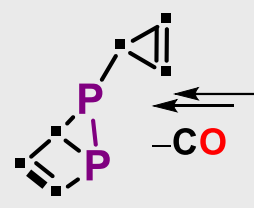

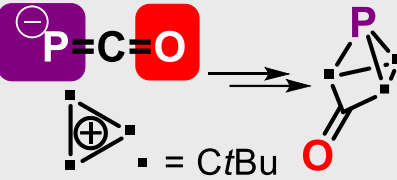<smiles>C#CC1=CP=CC1=O</smiles>

The reaction of 1,2,3-tris-tert-butylcyclopropenium tetrafluoroborate with sodium phosphaethynolate (NaOCP) is presented. Photolytic decarbonylation of the resulting product affords bis(cyclopropenyl)diphosphene and after rearrangement diphosphahousene, while its thermolysis provides access to phosphatricyclo[2.1.0.0]pentanone and phosphacyclopentadienone.
Tetiana Krachko, Andreas W. Ehlers, Martin Nieger, Martin Lutz, and J. Chris Slootweg*

Page No. - Page No.

Synthesis and Reactivity of the Phosphorus Analogues of Cyclopentadienone,

Tricyclopentanone, and Housene 